\title{
ILMIZI: Innovation Learning Model for Natural Science and Environmental Learning based on HOTS
}

\author{
IImi Zajuli Ichsan \\ Master Program of Biology Education, Faculty of Mathematics and Natural Science, Universitas Negeri Jakarta, Indonesia \\ ilmizajuli95@gmail.com; ilmi.zajuli@outlook.co.id \\ ${ }^{*}$ Corresponding Author
}

How to Cite : Ichsan, I., Z. (2019). ILMIZI: Innovation Learning Model for Natural Science and Environmental Learning based on HOTS. International Journal for Educational and Vocational Studies, 1 (6), 578-584

\section{ARTICLE HISTORY}

Received: 17 June 2019

Revised: 8 July 2019

Accepted: 12 September 2019

\section{KEYWORDS}

Environmental learning;

Higher Order Thinking Skills;

ILMIZI;

Learning Model;

Natural Science Learning;

\section{ABSTRACT}

Natural science and environmental learning in the $21^{\text {st }}$ century require Higher order thinking skills (HOTS). The purpose of this study was to develop an ILMIZI learning model. The method used is research and development carried out in June 2019. The results of the study showed that the ILMIZI model syntax consists of 6 stages, start from Identify problem, Limitation problem, Make mind map, Interpret result, Analyze result, Interaction and evaluate. The six stages are the results of development which are expected to have an impact on the rise of HOTS. Validation results from various learning experts and teachers showed a score of 3.74 with a percentage of $93.50 \%$ and a very valid category which means that the ILMIZI model is suitable for use in natural science learning (biology, physics, chemistry) and environmental learning at all levels of education. The conclusion is that the ILMIZI learning model was suitable for learning and expected to have an impact on HOTS students.

This is an open access article under the CC-BY-SA license.

\section{INTRODUCTION}

Natural science and environmental learning at all levels in the 21 st century need to be improved. This is because in the 21 st century, the ability of a student must have high competency. Capabilities needed in the 21st century learning such as critical thinking, collaboration, communication, and creativity (Boholano, 2017; Chalkiadaki, 2018; Farisi, 2016; Heinrichs, 2016; Smith, 2014). These abilities certainly have to start being trained since they were in elementary school to university level. One of the important abilities in the 21st century is Higher order thinking skills (HOTS), which have three aspects, consist of analyze, evaluate, and create (Anderson et al., 2001).

The problem that arises is that in natural science and the environment learning at all levels start from elementary school, junior high school, senior high school to university level is still not based on HOTS (Ichsan, Sigit, \& Miarsyah, 2019). This also resulted in HOTS scores of students in natural science and environmental learning still low. One component of learning that has an important role in increasing HOTS is the learning model (Husamah, Fatmawati, \& Setyawan, 2018; Saputri, Sajidan, Rinanto, Afandi, \& Prasetyanti, 2018; Tajudin \&
Chinnappan, 2016). In simple terms, the learning model is a model that consists of certain phase/syntax that directs learning to achieve learning goals. The use of learning models in the classroom is a necessity (Lewis, 2016; Muhlisin, 2018; Sandberg \& Ohman, 2011). But again, the development of HOTS-based learning models is still not widely done.

There are so many obstacles in the school that the teacher is difficult to develop a learning model. Even to use a simple learning model, there are still difficulties because there must be a lot of preparation (Anagün, 2018; Istiana \& Awaludin, 2018; Tajudin \& Chinnappan, 2016). Teachers with relatively large class of students will tend to choose learning models that are easy to do. This is a problem because to use a simple learning model that covers various aspects of HOTS is rather difficult. This is the basis for the need to develop a HOTS-based learning model that can be used for a small class of students or in large class.

Research in this world that discusses HOTS is true quite a lot that has been published starting from researching learning media to improve HOTS (Gruzd, Haythornthwaite, Paulin, Gilbert, \& del Valle, 2018; 
Yusop \& Sumari, 2013; Yusuf, Amin, \& Nugrahaningsih, 2017). Then identify HOTS student profiles (Abdullah et al., 2017; Dubas \& Toledo, 2016). However, for the development of learning models that do have the characteristics of HOTS, it has not been done much. Based on this, the development of the HOTS learning model needs to be done. The model developed must certainly answer the needs and problems that exist in the learning of natural science and the environment.

The model developed in this study is a learning model that is named ILMIZI (Identify, Limitation, Make mind map, Interpret, Analyze result, Interaction and evaluate). This learning model has characteristics that are considered suitable to answer the problems. Based on various things that have been described, the novelty of this research is an ILMIZI learning model that has characteristics based on HOTS. So the purpose of this study was to develop an ILMIZI learning model.

\section{METHODS}

This study was conducted in June 2019. The study method used was research and development according to Borg and Gall (2003) with modifications to the stages, namely (1) Data gathering (2) Designing learning models (3) Developing learning models (4) Expert validation (Gall,
Gall, \& Borg, 2003). In this study, no trials were conducted in class. This is because this study focuses on developing the ILMIZI learning model. While trials in the class were conducted in other research.

At the stage of data collection, an analysis of various literature sources and relevant research is carried out. The results showed that Natural science and environmental learning at various levels are not based on HOTS (Ichsan et al., 2019). This became the basis for the development of the ILMIZI learning model. The second stage is designing the learning model. At this stage, draft formulation was carried out and analyzed the suitability of the learning model with the curriculum. In the next stage, the syntax of the learning model is developed along with information on the activities of the teacher and students during the use of the ILMIZI model in the classroom.

The expert validation stage involved six validators consisting of 1 elementary school teacher (EST), 2 Junior High School teachers (JHST) and 1 Senior High School teacher (SHST). Meanwhile, 3 lectures as learning experts (LE). This expert validation was conducted to ask the opinions of experts and teachers regarding the learning model developed. The category of learning model validity can be seen in table 1 .

Table 1. Categories of validity for developing a learning model

\begin{tabular}{ccc}
\hline Interval Score & Percentage & Category \\
\hline $3,25<x \leq 4,00$ & $81 \%-100 \%$ & Very Valid \\
$2,50<x \leq 3,25$ & $61 \%-80 \%$ & Valid \\
$1,75<x \leq 2,50$ & $41 \%-60 \%$ & Less valid \\
$1,00<x \leq 1,75$ & $<40 \%$ & Not Valid \\
\hline
\end{tabular}

Source: adapted from Akbar (2013) and Ratumanan \& Laurens (2006))

\section{RESULTS AND DISCUSSIONS}

The results of the research and development showed the syntax (phase) of the ILMIZI learning model are (1) Identify problems (2) Limitation problems (3) Make Mind Map (4) Interpret result (5) Analyze result (6) Interact and evaluate. These six stages designed according to the characteristics of natural science and environmental learning at the elementary school, Junior high school, senior high school, and university level. The teacher and student activities in detail during the use of ILMIZI can be seen in table 2 .

Table 2. Syntax (phase) of ILMIZI learning model

\begin{tabular}{|c|c|c|c|}
\hline No & Syntax & Teacher activity & Students activity \\
\hline 1 & Identify problem & $\begin{array}{l}\text { Teacher gives a case/news/ short story that contains } \\
\text { problems to be solved by students related to natural } \\
\text { science and environmental issues }\end{array}$ & Students identify problems from cases/news/short story given by the teacher \\
\hline 2 & Limitation problem & Teacher divides students into several groups & $\begin{array}{l}\text { Students hold discussions with their groups and limit the problems of various } \\
\text { problems that have been identified }\end{array}$ \\
\hline 3 & Make Mind Map & $\begin{array}{l}\text { Teacher gives instructions for students to make a mind } \\
\text { map of the results of the discussions that have been } \\
\text { conducted }\end{array}$ & $\begin{array}{l}\text { Students make mind map from the results of group discussion. Every student } \\
\text { must make mind map, this is individual task. Making this mind map trains } \\
\text { student creativity }\end{array}$ \\
\hline 4 & Interpret result & $\begin{array}{l}\text { Teacher gives instructions for students to interpret the } \\
\text { results }\end{array}$ & $\begin{array}{l}\text { Students interpret and write the results of the discussion in the form of } \\
\text { paragraph descriptions on their notes }\end{array}$ \\
\hline 5 & Analyze result & $\begin{array}{l}\text { Teacher gives instructions for students to discuss with } \\
\text { other groups, and conduct further discussions }\end{array}$ & $\begin{array}{l}\text { Students discuss between groups. After that, the results of the discussion } \\
\text { between groups were made into a more in-depth analysis. Every student must } \\
\text { analyze and write the analysis in their note }\end{array}$ \\
\hline
\end{tabular}




\begin{tabular}{llll}
\hline 6 & $\begin{array}{l}\text { Interaction and } \\
\text { evaluate }\end{array}$ & $\begin{array}{l}\text { Teacher gives instructions for students to present their } \\
\text { result and analysis in front of the class and teacher } \\
\text { clarify if there is a wrong concept }\end{array}$ & $\begin{array}{l}\text { Students make presentations and describe the results of their discussions and } \\
\text { the results of their analysis to their classmates. Audience (other group) ask } \\
\text { a question and presenter answer the question. This process is an evaluate } \\
\text { stage from students to their friends }\end{array}$ \\
\hline
\end{tabular}

Table 3. Validity Score of ILMIZI model from expert and teacher based on each item

\begin{tabular}{|c|c|c|c|c|c|c|c|c|c|}
\hline No & Aspect & LE 1 & LE2 & LE3 & EST & JHST1 & JHST2 & SHST & Average \\
\hline 1 & Syntax is clear and easy to implement & 3.00 & 3.00 & 4.00 & 4.00 & 4.00 & 4.00 & 4.00 & 3.71 \\
\hline 2 & $\begin{array}{l}\text { Models can be used at all levels of education (elementary } \\
\text { /Junior or senior high school/ university) }\end{array}$ & 3.00 & 3.00 & 3.00 & 4.00 & 4.00 & 4.00 & 3.00 & 3.43 \\
\hline 3 & Student center based model & 4.00 & 4.00 & 4.00 & 4.00 & 4.00 & 4.00 & 4.00 & 4.00 \\
\hline 4 & $\begin{array}{l}\text { Models can be used in various materials for natural science and } \\
\text { environment learning }\end{array}$ & 4.00 & 4.00 & 3.00 & 3.00 & 4.00 & 4.00 & 4.00 & 3.71 \\
\hline 5 & $\begin{array}{l}\text { The model can train the ability of students in the 21st century, } \\
\text { one of them in collaborating and communicating }\end{array}$ & 4.00 & 4.00 & 4.00 & 4.00 & 3.00 & 4.00 & 4.00 & 3.86 \\
\hline 6 & The model has a syntax that stimulates the analysis of students & 4.00 & 4.00 & 4.00 & 4.00 & 4.00 & 4.00 & 3.00 & 3.86 \\
\hline 7 & The model has a syntax that stimulates student evaluation skills & 4.00 & 3.00 & 4.00 & 3.00 & 3.00 & 4.00 & 4.00 & 3.57 \\
\hline 8 & The model has a syntax that stimulates student creativity & 4.00 & 4.00 & 4.00 & 3.00 & 4.00 & 4.00 & 4.00 & 3.86 \\
\hline 9 & Using this model students can practice HOTS skills & 4.00 & 4.00 & 4.00 & 4.00 & 3.00 & 4.00 & 3.00 & 3.71 \\
\hline 10 & $\begin{array}{l}\text { This model is one form of innovation and has the potential to } \\
\text { increase HOTS }\end{array}$ & 4.00 & 4.00 & 4.00 & 4.00 & 4.00 & 3.00 & 3.00 & 3.71 \\
\hline
\end{tabular}

Note: Each item has a score range of 1-4; Learning expert (LE), Elementary School teacher (EST), Junior High School teacher (JHST), Senior High School teacher (SHST).

Table 4. Validation result and category

\begin{tabular}{|c|c|c|c|c|}
\hline & Score & Average & Percentage & Category \\
\hline Learning Expert 1 & 3.80 & & & \\
\hline Learning Expert 2 & 3.70 & & & \\
\hline Learning Expert 3 & 3.80 & & & \\
\hline Elementary Teacher & 3.70 & 3.74 & 93.50 & Very Valid \\
\hline Junior High School Teacher 1 & 3.70 & & & \\
\hline Junior High School Teacher 2 & 3.90 & & & \\
\hline Senior High School Teacher & 3.60 & & & \\
\hline
\end{tabular}

Based on the results of the validation in table 4 it can be concluded that ILMIZI has a very valid and suitable category to be used in natural science and the environment learning at all levels of education from elementary school, junior high school, senior high school, to university level. ILMIZI is an innovative learning model that is preceded by a problem identification step. In this step, students are given a case/news that contains problems. Students do not look for problems themselves like inquiry learning (Ahokoski, Korventausta, Veermans, \& Jaakkola, 2017; Hidayat, Wahyudin, \& Prabawanto, 2018; Markaki, 2014). That is because the ILMIZI does not emphasize students to look for problems but to analyze, evaluate, and create a solution according to HOTS-based competency. So that the case has been prepared by the teacher, plus if students are asked to look for their problems like inquiry, the analysis will be too broad and unfocused (Kinay \& Bagceci, 2016; Xia, 2017). Then the next step is to limit the problem. The aim is to limit the topics discussed to be focused. It is also for efficient learning time in class (Khan \& Masood, 2015; Utami, Sumarmi, Ruja, \& Utaya, 2016; K. K. Yang, Lee, Hong, \& Lin, 2016).

The ILMIZI syntax was developed based on HOTS aspect. In step 3 , every students make a mind map. This is part of the HOTS aspect of create. Making a mind map will stimulate students to be creative (Miller, 2018; Widiana, Jampel, \& Jampel, 2016; C.-M. Yang, 2018). Besides training students' creativity, making mind maps will also make it easier for students to understand the interrelationship between one concept and another. This continues with the next step, which is to interpret the results of the discussion on the topic being discussed in the group. Making mind maps by students will make it easier for them to interpret various data and results of discussion. That is because the link between the main points has been made in the form of a mind map (Chang, Chiu, \& Huang, 
2018; Daghistan, 2016; Polat, Yavuz, \& Tunc, 2017).

The next step is to interpret the result of discussion. In this section, students are asked to make interpretations of results after group discussions that have been conducted. The results of the interpretation are then written on a note or written using other media such as a laptop or gadget. After interpretation of the result, the next step is analyze the result. The results of the analysis are consist of arguments for the reasons to solve the problem. The results of the analysis are written by every student in group. This fifth step is clearly a step based on the HOTS aspect, namely analyze (Aisyah, Salehuddin, Aman, Yasin, \& Mimiko, 2018; Anderson et al., 2001; Copley, 2013; Gündüz, Alemdağ, Yaşar, \& Erdem, 2016).

The last phase or step is students are required to interact and evaluate. Interactions here, students presentations in front of their friends. At the presentation, there must be a question and answer between students who present with the audience. Students who act as audiences must asking questions. In this section, which is called evaluate, meaning that students who act as audiences conduct evaluations can provide suggestions or comments on students who presentation. At this stage, it is advantages ILMIZI from other learning models. In ILMIZI, students are required to ask each other questions and provide suggestions and comments as an evaluation step. The ability to evaluate this is related to the HOTS aspect (Anderson et al., 2001; Garcia, 2015; Narayanan \& Adithan, 2015).

The other advantage of ILMIZI is to have the characteristics of a HOTS based model on the syntax as described above. Also, ILMIZI also has characteristics that are suitable for natural science and environmental learning at all levels. ILMIZI can be used in biology, physics, chemistry, and environmental learning at various levels, start from elementary school, junior high school, high school seniors, to universities. ILMIZI prioritizes the discussion process between students to train students' communication skills (Mercer-Mapstone \& Kuchel, 2017; Wolfson \& Funke, 2014). Also, when making mind maps, the ability to collaborate is needed because students must discuss in group and then make mind map for every student after discuss. This shows that ILMIZI has an advantage because it is by the demands of ability in 21st-century learning (Boholano, 2017; Sadiqin, Sholahuddin, \& Santoso, 2017; Urbani et al., 2017).

Another advantage of ILMIZI in natural science and environmental learning is that the ILMIZI model has a syntax (phase) that trains students' ability to solve problems. In solving the problem, HOTS is needed, which is already available in the ILMIZI syntax. One example in the application of ILMIZI, for example, when students learn about the topic of environmental pollution, using ILMIZI can be started by identifying environmental pollution problems. Then the problem is limited. Limitation problem activities are intended to focus on the environmental problems that you want to solve (Khuana, Khuana, \& Santiboon, 2017; Thomas \& Fatherly, 2017). This is so that the problems solved are focused, for example, only focus on air pollution.

Then the third activity is making mind maps. The goal is to train student creativity. The low level of HOTS students in the create aspect can be improved by one of them by making a mind map. Making mind maps by students in addition to practicing creativity also makes students able to understand overall about the concepts in the topic. For example, when discussing air pollution, students will include components such as factors that cause air pollution. Then mention what substances are involved in the process of air pollution. The most important thing in making mind maps is not only seen in terms of appearance, but students can make mind maps that reflect important points of the material (Mustam \& Daniel, 2016; Polat et al., 2017).

The next step is the interpreted result. At this stage, students interpret the results from group discussions and interpret the results of the mind map that has been made. The results of the interpretation are recorded and continued in the fifth stage, namely analyzing. At this stage, the results of the interpretation are analyzed. Students are required to provide arguments about the problem of air pollution being solved. A good argument certainly must come from the student himself, not record what is already in the book. For example, students are asked to provide their analysis of air pollution. Students will connect these problems with facts that occur in everyday life regarding the environment (Gündüz et al., 2016; Kartikaningtyas, Kusmayadi, \& Riyadi, 2018).

Finally, after all the problem-solving activities are completed, students are required to interact by making presentations in front of the class, and other friends must comments and evaluate as the audience on the appearance of the presenter. In the end, the ILMIZI model is one solution that can be used to solve the low problem of HOTS that exists in students at various levels of elementary school, Junior High School, Senior High school to the university level. In practice, cooperation between various parties is needed to be able to change conventional learning habits and move to more relevant learning models and can increase HOTS (Afflerbach, Cho, \& Kim, 2015; Aisyah et al., 2018). The use of ILMIZI can also be combined with various learning media, learning materials, students worksheet, and others. It should also be developed learning materials, students worksheet, learning media, teaching materials, learning evaluation that have the characteristics of the ILMIZI learning model to support the implementation of the ILMIZI model in schools and universities.

\section{CONCLUSION}

The conclusion of this study was that the ILMIZI learning model has been successfully developed. The syntax/phase developed at ILMIZI includes six steps, namely Identify problem, Limitation problem, Make mind map, Interpret result, Analyze result, Interaction and evaluate. The ILMIZI model has also been validated and suitable for use in natural science and the environment learning at all 
levels of education start from elementary school, Junior high school, senior high school and university level. The ILMIZI model is one of the innovations in HOTS-based learning. The next development needs to be developed learning materials, student worksheets, learning media, teaching materials, learning evaluations and other supporting learning tools that have the characteristics of the ILMIZI learning model to support the implementation of the ILMIZI model in schools and university level. Other suggestion is implementation of ILMIZI learning model in learning to improve students HOTS.

\section{REFERENCES}

Abdullah, A. H., Mokhtar, M., Halim, N. D. A., Ali, D. F., Tahir, L. M., \& Kohar, U. H. A. (2017). Mathematics teachers' level of knowledge and practice on the implementation of higher-order thinking skills (HOTS). Eurasia Journal of Mathematics, Science and Technology Education, 13(1), 3-17. https://doi.org/10.12973/eurasia.2017.00601a

Afflerbach, P., Cho, B. Y., \& Kim, J. Y. (2015). Conceptualizing and Assessing Higher-Order Thinking in Reading. Theory into Practice, 54(3), 203-212.

https://doi.org/10.1080/00405841.2015.1044367

Ahokoski, E., Korventausta, M., Veermans, K., \& Jaakkola, T. (2017). Teachers' Experiences of an Inquiry Learning Training Course in Finland. Science Education International, 28(4), 305-314.

Aisyah, A., Salehuddin, K., Aman, I., Yasin, R. ., \& Mimiko, N. (2018). Eliciting Elements of Higher Order Thinking Skills in the Higher Secondary Examination Question Structure in Japan and Malaysia Aznur. In Proceedings of the Regional Conference on Science, Technology and Social Sciences (RCSTSS 2016) (pp. 455-464). Springer Singapore. https://doi.org/10.1007/978-981-13-0074-5

Akbar, S. (2013). Instrumen Perangkat Pembelajaran. Bandung: PT. Remaja Rosdakarya.

Anagün, Ş. S. (2018). Teachers' Perceptions about the Relationship between 21st Century Skills and Managing Constructivist Learning Environments. International Journal of Instruction, 11(4), 825-840. https://doi.org/10.12973/iji.2018.11452a

Anderson, L. W., Krathwohl, D. R., Airiasian, W., Cruikshank, K. A., Mayer, R. E., \& Pintrich, P. R. (2001). A taxonomy for learning, teaching and assessing: A revision of Bloom's Taxonomy of educational outcomes: Complete edition. New York: Longman.

Boholano, H. B. (2017). Smart Social Networking: 21st Century Teaching And Learning Skills. Research in Pedagogy, $7(1)$, 21-29. https://doi.org/10.17810/2015.45

Chalkiadaki, A. (2018). A Systematic Literature Review of 21st Century Skills and Competencies in Primary Education. International Journal of Instruction, 11(3),
1-16. https://doi.org/10.12973/iji.2018.1131a

Chang, J. H., Chiu, P. S., \& Huang, Y. M. (2018). A sharing mind map-oriented approach to enhance collaborative mobile learning With digital archiving systems. International Review of Research in Open and Distributed Learning, 19(1), 1-24.

Copley, P. (2013). The Need to Deliver Higher-Order Skills in the Context of Marketing in SMEs. Industry and Higher Education, 27(6), 465-476. https://doi.org/10.5367/ihe.2013.0181

Daghistan, B. I. A. M. (2016). Mind Maps to Modify Lack of Attention among Saudi Kindergarten Children. International Education Studies, 9(4), 245-256. https://doi.org/10.5539/ies.v9n4p245

Dubas, J. M., \& Toledo, S. A. (2016). Taking higher order thinking seriously: Using Marzano's taxonomy in the economics classroom. International Review of Economics Education, 21, 12-20. https://doi.org/10.1016/j.iree.2015.10.005

Farisi, M. I. (2016). Developing the 21 st-century social studies skills through technology integration. Turkish Online Journal of Distance Education-TOJDE, 17(1), 16-30. https://doi.org/10.17718/tojde.47374

Gall, M. D., Gall, J. P., \& Borg, W. R. (2003). Educational Research An Introduction. San Fransisco: Pearson Education.

Garcia, L. C. (2015). Environmental Science Issues for Higher- Order Thinking Skills (HOTS) Development: A Case Study in the Philippines. In Biology Education and Research in a Changing Planet (pp. 45-54). https://doi.org/10.1007/978-981-287-524-2

Gruzd, A., Haythornthwaite, C., Paulin, D., Gilbert, S., \& del Valle, M. E. (2018). Uses and Gratifications factors for social media use in teaching: Instructors' perspectives. New Media \& Society, 20(2), 475-494. https://doi.org/10.1177/1461444816662933

Gündüz, A. Y., Alemdă̆, E., Yaşar, S., \& Erdem, M. (2016). Design of a Problem-Based Online Learning Environment and Evaluation of its Effectiveness. The Turkish Online Journal of Educational Technology, 15(3), 49-57. https://doi.org/10.1017/CBO9781107415324.004

Heinrichs, C. R. (2016). Exploring the Influence of 21st Century Skills in a Dual Language Program: A Case Study. International Journal of Teacher Leadership Heinrichs - Exploring the Influence, 37(1), 37-56. Retrieved

from http://files.eric.ed.gov/fulltext/EJ1137667.pdf

Hidayat, W., Wahyudin, W., \& Prabawanto, S. (2018). Improving students, creative mathematical reasoning ability students through adversity quotient and argument driven inquiry learning. Journal of Physics: Conference Series, 948.

Husamah, H., Fatmawati, D., \& Setyawan, D. (2018). OIDDE Learning Model: Improving Higher Order Thinking Skills of Biology Teacher Candidates. Interntaional Journal of Instruction, 11(2), 249-264. 
Ichsan, I. Z., Sigit, D. V., \& Miarsyah, M. (2019). Environmental Learning Based on Higher Order Thinking Skills: A Needs Assessment. International Journal for Educational and Vocational Studies, 1(1), 21-24. https://doi.org/10.29103/ijevs.v1i1.1389

Istiana, R., \& Awaludin, M. T. (2018). Enhancing biology education students ability to solve problems in environmental science material through inquiri model-based lesson study. Biosfer: Jurnal Pendidikan Biologi, 11(1), 57-66. https://doi.org/https://doi.org/10.21009/biosferjpb.11-1 6

Kartikaningtyas, V., Kusmayadi, T. A., \& Riyadi, R. (2018). The effect of brain based learning with contextual approach viewed from adversity quotient The effect of brain based learning with contextual approach viewed from adversity quotient. Journal of Physics: Conference Series, 1022.

Khan, F. M. A., \& Masood, M. (2015). The Effectiveness of an Interactive Multimedia Courseware with Cooperative Mastery Approach in Enhancing Higher Order Thinking Skills in Learning Cellular Respiration. Procedia - Social and Behavioral Sciences, $\quad 176, \quad 977-984$. https://doi.org/10.1016/j.sbspro.2015.01.567

Khuana, K., Khuana, T., \& Santiboon, T. (2017). An instructional design model with the cultivating research-based learning strategies for fostering teacher students creative thinking abilities. Educational Research and Reviews, 12(15), 712-724. https://doi.org/10.5897/ERR2017.3239

Kinay, I., \& Bagceci, B. (2016). The Investigation of the Effects of Authentic Assessment Approach on Prospective Teachers' Problem-Solving Skills. International Education Studies, 9(8), 51-59. https://doi.org/10.5539/ies.v9n8p51

Lewis, C. (2016). How does lesson study improve mathematics instruction? ZDM - Mathematics Education, 48(4), 571-580. https://doi.org/10.1007/s11858-016-0792-x

Markaki, V. (2014). Environmental Education through Inquiry and Technology. Science Education International, 25(1), 86-92.

Mercer-Mapstone, L., \& Kuchel, L. (2017). Core Skills for Effective Science Communication: A Teaching Resource for Undergraduate Science Education. International Journal of Science Education, Part B: Communication and Public Engagement, 7(2), 181-201. https://doi.org/10.1080/21548455.2015.1113573

Miller, A. L. (2018). The Role of Creative Coursework in Skill Development for University Seniors. Global Education Review, 5(1), 88-107.

Muhlisin, A. (2018). Analysis of students'response of the implementation of rms (reading, mind mapping, and sharing) learning model in philosophy of science. Unnes Science Education Journal, 7(1).

Mustam, B., \& Daniel, E. S. (2016). Informal and Formal
Environmental Education Infusion: Actions of Malaysian Teachers and Parents among Students in a Polluted Area. Malaysian Online Journal of Educational Sciences, 4(1), 9-20. Retrieved from http://www.moj-es.net/frontend/articles/pdf/v04i01/v0 4-i01-01.pdf

Narayanan, S., \& Adithan, M. (2015). Analysis of Question Papers in Engineering Courses with Respect to HOTS (Higher Order Thinking Skills). American Journal of Engineering Education, 6(1), 1-10.

Polat, O., Yavuz, E. A., \& Tunc, A. B. O. (2017). The effect of using mind maps on the development of maths and science skills. Cypriot Journal of Educational Sciences, 12(1), 32-45.

Ratumanan, T. ., \& Laurens, T. (2006). Evaluasi Hasil Belajar yang Relevan dengan Kurikulum Berbasis Kompetensi. Surabaya: Unesa University Press.

Sadiqin, I. K., Sholahuddin, A., \& Santoso, U. T. (2017). Students 'Difficulties on Science Learning with Prototype Problem-Solving Based Teaching and Learning Material: A Study Evaluation of Development Research. Advances in Social Science, Education and Humanities Research, 100, 279-282.

Sandberg, K. W., \& Ohman, G. (2011). Learning in innovation development. Procedia - Social and Behavioral Sciences, 28, 379-383. https://doi.org/10.1016/j.sbspro.2011.11.072

Saputri, A. C., Sajidan, S., Rinanto, Y., Afandi, A., \& Prasetyanti, N. M. (2018). Improving Students' Critical Thinking Skills in Cell-Metabolism Learning Using Stimulating Higher Order Thinking Skills Model. International Journal of Instruction, 12(1), 327-342. https://doi.org/10.29333/iji.2019.12122a

Smith, T. (2014). Elementary Science Instruction: Examining a Virtual Environment for Evidence of Learning, Engagement, and 21st Century Competencies. Education Sciences, 4(1), 122-138. https://doi.org/10.3390/educsci4010122

Tajudin, N. M., \& Chinnappan, M. (2016). The Link between Higher Order Thinking Skills, Representation and Concepts in Enhancing TIMSS Tasks. International Journal of Instruction, 9(2), 199-214. https://doi.org/10.12973/iji.2016.9214a

Thomas, J. F., \& Fatherly, S. (2017). The Roadmap Seminar: Preparing Students for Success in Learning Communities. Learning Communities: Research \& Practice, 5(2), 7. Retrieved from http://libproxy.usc.edu/login?url=https://search.proqu est.com/docview/2011264524?accountid=14749

Urbani, J. M., Truesdell, E., Urbani, J. M., Roshandel, S., Michaels, R., \& Truesdell, E. (2017). Developing and Modeling 21st-Century Skills with Preservice Teachers. Teacher Education Quarterly, 44(4), 27-51.

Utami, W. S., Sumarmi, S., Ruja, I. N., \& Utaya, S. (2016). The Effectiveness of Geography Student Worksheet to Develop Learning Experiences for High School Students. Journal of Education and Learning, 5(3), 315-321. https://doi.org/10.5539/jel.v5n3p315 
Widiana, I. W., \& Jampel, I. N. (2016). Improving Students' Creative Thinking and Achievement through The Implementation of Multiple Intelligence Approach with Mind Mapping. International Journal of Evaluation and Research in Education (IJERE), 5(3), $246-254$.

Wolfson, T., \& Funke, P. N. (2014). Communication, class and concentric media practices: Developing a contemporary rubric1. New Media and Society, 16(3), 363-380. https://doi.org/10.1177/1461444813481199

Xia, B. S. (2017). An In-Depth Analysis of Teaching Themes and the Quality of Teaching in Higher Education: Evidence from the Programming Education Environments. International Journal of Teaching and Learning in Higher Education, 29(2), 245-254. Retrieved from http://search.ebscohost.com.proxy-ub.rug.nl/login.asp $\mathrm{x}$ ?direct=true \&db=eric\&AN=EJ1146146\&site=ehost-1 ive\&scope $=$ site

Yang, C.-M. (2018). Applying Design Thinking as a Method for Teaching Packaging Design. Journal of Education and Learning, 7(5), 52-61. https://doi.org/10.5539/jel.v7n5p52

Yang, K. K., Lee, L., Hong, Z. R., \& Lin, H. S. (2016). Investigation of effective strategies for developing creative science thinking. International Journal of Science Education, 38(13), 2133-2151. https://doi.org/10.1080/09500693.2016.1230685

Yusop, F. D., \& Sumari, M. (2013). The Use of Social Media Technologies among Malaysian Youth. Procedia Social and Behavioral Sciences, 103, 1204-1209. https://doi.org/10.1016/j.sbspro.2013.10.448

Yusuf, M. M., Amin, M., \& Nugrahaningsih. (2017). Developing of Instructional Media-Based Animation Video on Enzyme and Metabolism Material. Jurnal Pendidikan Biologi Indonesia, 3(3), 254-257. 